\title{
Financial Institutions and Firm Efficiency in the Gulf Cooperation Council Countries
}

\author{
Reza Haider Chowdhury \\ College of Business Administration, Department of Finance and Banking \\ University of Dubai, PO Box 14143 \\ Dubai, United Arab Emirates
}

Tel: 971-4-207 2683 E-mail: rchowdhury@ud.ac.ae

\author{
Received: December 1, 2011 \\ Accepted: December 19, 2011 \\ Published: March 1, 2012 \\ doi:10.5539/ijef.v4n3p170 \\ URL: http://dx.doi.org/10.5539/ijef.v4n3p170
}

The author greatly acknowledges the support provided by the University of Dubai, UAE.

\begin{abstract}
The aim of this study is to estimate the level of firm efficiency in the Gulf Cooperation Council countries including Bahrain, Kuwait, Oman, Qatar, Saudi Arabia, and the United Arab Emirates. The paper also identifies the relationship of individual firm-specific characteristics with firm efficiency in these countries. The result exhibits that the level of firm efficiency ranges from $62 \%$ to $69 \%$ in the region. However, the magnitude of this efficiency varies across different industries and among individual countries. The result also suggests that financial institutions play an insignificant role in improving firm efficiency in the region. In contrast, the level of efficiency increases as a result of improving firm's own financial performance. These findings are indeed useful for potential investors in their portfolio investment decisions, and for policymakers in initiating necessary measures to strengthen the contribution of financial institutions in the region.
\end{abstract}

Keywords: Firm efficiency, Financial institutions, The Gulf Cooperation Council Countries, Stochastic frontier approach

\section{Introduction}

There are several papers in extant literature that examine the efficiency of banks and financial institutions in the Gulf Cooperation Council (GCC) countries (See Marie et al. 2009; Rao, 2005). However, none of the studies determines the efficiency level of non-financial firms of the region. This study bridges such gap in the literature by addressing the following four questions: Are GCC firms efficient? Is there any trend of improvement in firm efficiency throughout the region? Which industry in the GCC countries is the most/least efficient? Does firm-level efficiency vary across six GCC countries? Further, earlier studies in corporate finance determine several significant roles of financial institutions in enhancing firm's operating efficiency. For instance, an efficient financial institution can produce information ex ante about possible investments, as well as monitor investments and exert corporate governance after providing finance (see Stulz, 2000; Walsh and Ryan, 1997). In addition, a high level of debt outstanding reduces managerial cash flow waste through the threat of liquidation (see Grossman and Hart, 1986) or through pressure to generate cash flows to service debt (see Jensen, 1986). Therefore, the disciplinary and monitoring roles of financial institutions create an external pressure on managers to become more competent and transparent, and thus can help firms to outperform. The question remains whether financial institutions in the GCC countries perform such roles successfully in order to improve firm efficiency in this region. The paper addresses this question by examining the effectiveness of financial institutions in accelerating firm efficiency in six GCC countries including Bahrain, Kuwait, Oman, Qatar, Saudi Arabia, and the United Arab Emirates. Finally, the paper identifies the key determinants of firm's operating efficiency by examining the relationship between firm efficiency and several firm-specific factors including operating cash flows, profitability, growth, firm size, future investment opportunity, and asset turnover.

The level of firm efficiency is estimated by using the Stochastic Frontier Model (SFM), introduced by Aigner et al. (1977). Three different functional forms of SFM including fixed-effects, translog, and flexible-fourier specifications are used to calculate such efficiency. In my knowledge, there is no paper in extant literature that considers all three functional forms to estimate firm efficiency particularly for GCC companies. This study is also the first research on the GCC countries that considers a large panel dataset over the period 2001-2010. 
The result exhibits that the publicly-listed GCC firms are quite inefficient. ${ }^{1}$ In particular, the level of firm efficiency varies from $62 \%$ to $69 \%$. Further, the result shows that there were no significant changes in efficiency of GCC firms over the last ten years. Among individual industries, the construction industry is relatively less efficient among all other sectors of the region. Among the GCC countries, firms located in Kuwait and Qatar are comparatively more inefficient than individual companies in the remaining four countries. Further analysis reveals that high amount of debt and large interest payments by individual firms do not have any significant effect on firm efficiency, suggesting that an increase in external borrowing from banks and other financial institutions do not necessarily force GCC firms to become more efficient. In other words, the disciplinary and monitoring roles of financial institutions are not sufficient to improve firm efficiency in the case of GCC firms. This evidence is not unlikely given that financial institutions in the GCC countries are still inefficient (refer to Section 3). In contrast, the result suggests that an increase in firm efficiency is mainly driven by an improvement in operating cash flows, net margin, asset turnover, and future investment opportunity of individual firms. Therefore, managers' active participation and their competency in managing internally generated resources result in high firm efficiency in the GCC countries.

The rest of the paper is organized as follows. Section 2 mentions the recent emerging activities of the GCC countries. Section 3 discusses the key hypothesis based on the findings in extant literature. Section 4 describes sample data, theoretical models and econometric methodology. Section 5 analyzes the estimated results, and section 6 concludes the paper.

\section{Background about the GCC Countries}

The GCC countries are highly comparable because of their geographical proximity and the similarity of regulations, economic and social conditions. Over the past one decade, the GCC countries changed their priority from oil-based economic system to market-driven and production-oriented economic model. By constant reforms and infrastructural development, this region is now one of the fastest growing and highly competitive markets in the world. As IMF (International Monetary Fund) record shows, the GCC countries achieved an average growth of 6.6 percent a year during the period 2003-2008 (see Khamis and Senhadji, 2010). Further, the annual growth of non-oil sector increased from 4.8 percent in 1997-2002 to 7.3 percent in 2003-2008. Additionally, the size of total fixed investments in the GCC countries increased by more than eight times from $\$ 300$ billion in 2004 to $\$ 2.5$ trillion in 2008. At the same time, total bank credit to the private sector of six GCC countries, particularly in Qatar and the United Arab Emirates (UAE), grew at roughly 23 percent a year during the period 2004-2008. Because of this rapid growth in the credit market, the fraction of private sector credit to non-oil GDP increased to almost 122 percent by the end of 2008. Subsequent changes in economic and social infrastructures finally converted this region into a business-friendly environment by the end of 2010 .

\section{Literature Review and Hypothesis}

Earlier studies analyzed both credit and stock market efficiencies in the Gulf countries. Mostafa (2007), for example, examines the operating efficiency of several commercial banks in six GCC countries, and find that the performance of many banks in the region is sub-optimal, suggesting the potential for significant improvement in the banking industry in the GCC. By applying non-parametric frontier approach, Ariss et al. (2007) find that while banks in Oman are on average the most efficient, banks in Saudi Arabia are the least efficient in the GCC countries. They also find that low efficient banking environment is continuing for several years in Qatar and the UAE. They determine that such variations in bank performance across the GCC countries are mainly resulted from significant differences in productivity and scale inefficiencies among banks. Finally, Srairi (2010) finds that banks in the Gulf region are relatively more efficient in generating profits than in controlling costs.

Several other studies examine stock market efficiency in the GCC. For instance, Abdmoulah (2010) argues that the equity markets in the GCC countries are weak-form efficient with no significant changes until the first quarter of 2009. Likewise, Asiri (2008) measures the behavior of stock prices in the Bahrain Stock Exchange, and finds random walk with no drift and trend for all daily stock prices. Similarly, Hassan et al. (2003) find that the Kuwait Stock Exchange is also weak-form efficient because of low market liquidity, lack of high quality information, and restriction on institutional trading. Using more recent data, Smith (2007) and Squalli (2006) also find similar evidence in the case of Oman and the UAE stock markets, respectively.

In summary, the extant literature highlights that banks and stock markets in the GCC are less efficient in retrieving inside information, ensuring credit quality, and enforcing good corporate governance due to their own allocation and technical inefficiencies. This eventually increases the chance of misusing firm's internal resources by managers, and thereby adversely affects on firm performance. I therefore assume that banks and other financial institutions of the region play an insignificant role in improving firm efficiency in the GCC countries. 


\section{Data, Empirical Models and Estimation Method}

In the paper, the empirical model includes two steps of regression analysis. The first stage regression model estimates the magnitude of firm inefficiency in the GCC countries. In the second stage regression model, I use such inefficiency measures to determine whether and how a firm's external source of financing and other firm-specific determinants influence the existing level of firm inefficiency.

\subsection{Data}

To estimate the coefficients of both first- and second-stage regression models, I use an unbalanced panel dataset, clustered by firm. The dataset consists of financial data of all publicly-listed non-financial and non-utility GCC firms. Accordingly, there are 15 companies from Bahrain, 131 companies from Kuwait, 96 companies from Oman, 15 companies from Qatar, 90 companies from Saudi Arabia, and 38 companies from the UAE in the dataset. All these 385 companies mainly belong to six major industries of the GCC countries including construction, energy, food, manufacturing, services, and tourism. In this paper, I cover a sample period from 2001 to 2010. Because of missing data of several firms in certain years, the magnitude of firm inefficiency is finally estimated from total 2219 firm-year observations. I collect the data from Zawya, an electronic database that consists of financial and non-financial information about all publicly-listed companies in the GCC stock markets.

\subsection{First Stage Regression Model}

I measure the level of firm inefficiency by conducting the stochastic frontier analysis (SFA), developed by Meeusen and Broeck (1977) and Aigner et al. (1977). The general expression of the stochastic frontier model is:

$$
Y=\beta^{\prime} X+v-u
$$

In the model, $Y$ is the observed outcome, and $X$ 's are the set of exogenous variables that affect firm's output variable. The optimal frontier goal is expressed by $\left(\beta^{\prime} X+v\right)$ in which $\beta^{\prime} X$ is the deterministic part of the frontier, and $v$ is a systematic error component that allows random variation of the frontier across firms and captures the effects of measurement error, individual statistical noises and random shocks beyond firm's control. The last term in the model, $u$, is an error component that captures the effects of both technical and allocative inefficiencies of individual firms relative to their best-practice level. SFA allows four different distributions of the inefficiency term $(u)$, such as half-normal, exponential, truncated and gamma distributions. This paper reports the estimated parameters of stochastic frontier model based on the exponential distribution of $u .^{2}$

To specify the SFA revenue function of Model (1), I employ three alternative functional forms including (i) fixed-effects; (ii) translog, and (iii) flexible fourier specifications.

\subsubsection{Fixed-effects Specification}

The frontier regression model under this functional form is specified as follows:

$$
\operatorname{Ln}\left(Y_{i t}\right)=\alpha+\beta \cdot \operatorname{Ln}\left(W_{i t}\right)+\gamma \cdot \operatorname{Ln}\left(Q_{i t}\right)+\delta . D_{i}+\eta \cdot T_{t}+\varepsilon_{i t}
$$

Here, $Y_{i t}$ is the observed output variable of firm $i$ at year $t$. $W_{i t}$ are two separate input variables, and $Q_{i t}$ includes a vector of control variables. $D_{i}$ is a set of industry- and country-specific dummy variables, and $T$ is a vector of year-specific dummy variables. $\beta, \gamma, \delta$ and $\eta$ are estimated coefficients of corresponding variables, and $\varepsilon$ is the error term, which is equal to $(v-u)$.

\subsubsection{Translog Specification}

The translog function usually consists of both linear and quadratic terms. The function can be approximated by second order Taylor series. Accordingly, the translog revenue function is specified as follows:

$$
\begin{gathered}
\operatorname{Ln}\left(Y_{i t}\right)=\alpha_{0}+\sum_{i} \beta_{i} \cdot \operatorname{Ln}\left(Q_{i t}\right)+\sum_{i} \gamma_{i} \cdot \operatorname{Ln}\left(W_{i t}\right)+\sum_{j} \delta_{j} \cdot D_{j}+\eta_{t} \cdot T_{t}+0.5 \sum_{i} \alpha_{i}\left(\operatorname{Ln} Q_{i t}\right)^{2}+0.5 \sum_{i} \omega_{i}\left(\operatorname{Ln} W_{i t}\right)^{2} \\
\sum_{i} \sum_{j} \beta_{j \cdot}\left(\operatorname{Ln} Q_{i t}\right)\left(\operatorname{Ln} Q_{j t}\right)+\sum_{i} \xi_{i}\left(\operatorname{Ln} Q_{i t}\right)\left(\operatorname{Ln} W_{i t}\right)+\varepsilon_{i t}
\end{gathered}
$$

In addition to individual terms of equation (2-1), the above specification includes two separate square terms of input $\left(W_{i t}\right)$ and output variables $\left(Q_{i t}\right)$, cross-product terms between $Q_{i t}$ and $W_{i t}$, and between $Q_{i t}$ and $Q_{j t}$. Therefore, the estimated results include nine additional terms in translog specification compared to that in the fixed-effects model. All variables are expressed in natural logs.

\subsubsection{Flexible Fourier Specification}

The flexible fourier specification represents a semi-non-parametric approach to the problem of using the data to infer interrelationships among the variables when the true functional form of the relationships is unknown (Mitchell and Onvural, 1996). Though the functional form requires an indefinite number of trigonometric terms, I consider a 
limited number of terms in the revenue function because of a finite number of observations of individual variables. Gallant (1981) finds that a fourier series representation of an unknown function can achieve a given level of approximation error with fewer trigonometric terms when it includes a second-order polynomial in the explanatory variables. Accordingly, the flexible fourier specification of the revenue function is expressed as follows:

$$
\begin{aligned}
\operatorname{Ln}\left(Y_{i t}\right)= & \alpha_{0}+\sum_{i} \beta_{i \cdot} \operatorname{Ln}\left(Q_{i t}\right)+\sum_{i} \gamma_{i} \operatorname{Ln}\left(W_{i t}\right)+\sum_{j} \delta_{j} \cdot D_{j}+\eta_{t} \cdot T_{t}+0.5 \sum_{i} \alpha_{i}\left(\operatorname{Ln} Q_{i t}\right)^{2}+0.5 \sum_{i} \omega_{i}\left(\operatorname{Ln} W_{i t}\right)^{2} \\
& +\sum_{i} \sum_{j} \beta_{j \cdot}\left(\operatorname{Ln} Q_{i t}\right)\left(\operatorname{Ln} Q_{j t}\right)+\sum_{i} \xi_{i}\left(\operatorname{Ln} Q_{i t}\right)\left(\operatorname{Ln} W_{i t}\right)+\sum_{j=1}^{2}\left[\varphi_{j} \cos Q_{j}+\vartheta_{j} \sin Q_{j}\right]+ \\
& \sum_{j=1}^{2} \sum_{k=1}^{2}\left[\varphi_{j k} \cos \left(Q_{j}+Q_{k}\right)+\vartheta_{j k} \sin \left(Q_{j}+Q_{k}\right)\right]+\varepsilon_{i t}
\end{aligned}
$$

The definition of each variable is the same as in the previous two specifications (2-1 and 2-2). While the first eight terms of equation (2-3) represent the translog series of the flexible fourier revenue function, the last two terms consist of sine and cosine expressions of output variables to identify the truncated fourier series.

\subsubsection{Estimation Method}

The unknown parameters of Model (1) are estimated using the maximum likelihood (ML) method. The idea behind the ML estimation is to determine the value of a parameter that maximizes the probability (likelihood) of the sample data. There are several other parameters, estimated from Model (1), that have important implications for the analysis. First, the parameter $\theta$ is defined as $1 / \sigma_{u}$ in the normal-exponential model. In general, $\theta \rightarrow 0$ implies that there are no operational inefficiency effects and all deviations from the frontier are mainly due to statistical noise. Therefore, I conduct a hypothesis test, such as $\mathrm{H}_{0}: \theta=0$ against $\mathrm{H}_{1}: \theta>0$, to examine the significance of $\theta$. Second, total variance of the combined error term can be expressed as $\left(\sigma_{v}^{2}+\sigma_{u}^{2}\right)$. Between these two terms, $\sigma_{u}{ }^{2}$ denotes the volatility of error component in the stochastic frontier model that is associated with operational inefficiency, and therefore can be manageable by reallocating internal resources of firms, while $\sigma_{v}{ }^{2}$ captures the remaining fraction of volatility in error term that is uncontrollable by individual firms. Therefore, in the case of $\sigma_{u}{ }^{2}>\sigma_{v}{ }^{2}$, the GCC companies should be able to reduce their operating inefficiencies by further improving the allocation of internal resources (i.e., labor, capital and other resources). The parameters of log-likelihood function is usually estimated by taking the first order derivatives of the function with respect to unknown parameters and setting them equal to zero. However, since these first order conditions are highly nonlinear and cannot be solved analytically for $\sigma$ and $\theta$, the likelihood function is usually maximized using an iterative optimization procedure. This involves selecting starting values for the unknown parameters and systematically updating them until the values that maximize the $\log$-likelihood function are found. In this study, I use the econometric software, called LIMDEP, to estimate all these parameters. The stochastic frontier model in LIMDEP can be expressed as follows:

$$
\operatorname{Ln} Y_{i t}=X_{i t} \cdot \beta+v_{i t}-u_{i t}, i=1,2,3, \ldots \ldots, \mathrm{N} \text { and } t=2001,2002, \ldots ., 2010
$$

where, $v_{i t} \sim \operatorname{iidN}\left(0, \sigma_{v}^{2}\right)$ and $u_{i t} \sim \theta$.exp $(-\theta u)$ as described in Meeusen and Broeck (1977). Based on the estimated parameters of (3-1), the expected firm inefficiency, $\mathrm{E}[u \mid v-u]$, is finally calculated in LIMDEP by the following equation (see Jondrow et al., 1982):

$$
\hat{E}(u \mid v-u)=\sigma_{v} \cdot[\varnothing(z) /(1-\Phi(z))]-z, \text { where } z=\left(\varepsilon / \sigma_{v}\right)+\theta \cdot \sigma_{v} \text { and } \varepsilon=v-u
$$

Consistent with Leibenstein (1966) and Kozmetsky and Yue (1998), I consider that a firm is efficient if the manager of that firm spends lesser amount of resources in production and administrative expenses while simultaneously generates a greater amount of sales revenue. I therefore calculate firm inefficiency by estimating a revenue frontier model. As such, the output variable in the model is firm's sales revenue. Further, I describe $X_{i}=\left(W_{i}, Q_{i}, Z_{i}\right)$ as a set of firm-specific exogenous variables that affect firm's total revenue. Among them, $W_{i}$, expressed in natural logs, are two input variables including the cost of goods sold (COGS), and selling, general and administrative expenses ( $S G A)$ of individual firms. ${ }^{3}$ By definition, $C O G S$ is total cost of labors and raw materials associated with the production of goods and/or services, and $S G A$ includes total cost related to advertising, sales, distributions and promotions as well as officers' payrolls and bonuses, directors' remuneration and fringe benefits. $Q_{i}$ includes two additional output quantities, expressed in natural logs, including firm's total assets $(T A)$ and plants, property and equipments $(F A)$. $T A$ is the sum of current assets (i.e., cash and marketable securities, accounts receivables, inventories) and fixed assets (i.e., lands, buildings, machineries and equipments plus other long term investments). Additionally, $F A$ is total physical assets net off annual depreciation of assets. In the model, $T A$ and $F A$ are considered as two separate control variables. Finally, $Z_{i}$ includes three different dummy variables $(0,1)$ indicating (a) the sample year, (b) the industry in which a sample firm belongs to, and (c) the country where a firm is incorporated. In the analysis, I consider 2001 as a base year, the energy sector as a base industry, and the UAE as a base country. ${ }^{4}$

\subsection{Second Stage Regression Model}

In the paper, the second-stage regression model is specified as follows: 


$$
\begin{array}{r}
u_{i t}=\text { Constant }+\alpha_{l}(\text { Firm's Exposure to Banks })_{i t}+\sum_{k=1}^{6} \beta_{k}(\text { Firm Characteristics })_{i t}+\delta_{i} T_{i}+ \\
\gamma_{i \cdot I N D_{i}+\varphi_{i} \cdot C_{i}+\zeta_{i t}}
\end{array}
$$

Here, $u_{i t}$ is the level of firm inefficiency at year $t$, estimated from equations (2-1) - (2-3). To measure a firm's dependence on banks and other financial institutions, I consider two alternative measures: (a) firm's leverage (LEV) and (b) total interest payments (INT). High financial leverage mitigates the conflict between shareholders and managers concerning the choice of investment (e.g., Myers, 1977), the amount of risk to undertake (e.g., Jensen and Meckling, 1976; Williams, 1987), the conditions under which the firm is liquidated (e.g., Harris and Raviv, 1990), and the problem associated with dividend policy (e.g., Stulz, 1990). In addition, managers remain under pressure to generate sufficient cash flows to pay interests in the presence of high leverage (e.g., Jensen, 1986). I therefore posit that managers' high commitment to fulfill debt related obligations motivates them to make more effective decisions. In the paper, I define $L E V$ as a ratio of total long-term debt to total assets, and $I N T$ as a ratio of total interest payments to total assets of individual firms.

To measure firm's own financial performance, I consider firm's (a) operating cash flows $(O C F)$, a ratio of cash-flows from operating activities to total assets, (b) asset turnover $(T A)$, a ratio of sales revenue to total assets of a firm, (c) net margin $(N M)$, a ratio of net profit to total sales, (d) sales growth $(G R)$, a change in current sales revenue, (e) future investment opportunity (INVOPP), a ratio of firm's market value of equity to book value of total assets less total liabilities, and (f) firm size (SIZE), logarithm of total assets, in Model (4). I include year dummy variables $(T)$ to observe whether firm-level inefficiency had been changed over time during the sample period. Likewise, I include country- $(C)$ and industry-specific $(I N D)$ dummy variables to observe whether the level of firm inefficiency vary across individual countries and different industries in the GCC region. I finally estimate the coefficients of Model (4) by using the fixed-effect panel regression method.

\section{Empirical Results and Analysis}

\subsection{Characteristics of GCC Firms}

Table 1 reports the summary statistics of individual key variables that have been used in the first- (Panel A) and the second-stage (Panel B) regression models. Since different functional forms of the first stage regression model include the logarithm of input and output variables, the table summarizes the mean, standard deviation and skewness of $\log$ values of each indicator in Panel A. Column I of Panel A, for example, reports the estimated statistics of logarithm of sales revenue (lnREV). I find that average $\ln R E V, \ln C O G S$, and $\ln S G A$ range from 16.55 to 18.54 , from 16.15 to 18.03 , and from 14.47 to 16.24 , respectively. Therefore, the average sales revenue, cost of production, and SGA expenses of GCC firms vary in between $\$ 15$ million and \$113 million, between $\$ 10$ million and \$68 million, and between $\$ 2$ million and $\$ 11$ million, respectively. In addition, the average total assets (fixed assets) range from $\$ 31$ million to $\$ 569$ million (from $\$ 11$ million to $\$ 102$ million) among the GCC firms.

Panel B includes two key variables of the second stage regression model. The result exhibits that the publicly-listed firms in Oman (Bahrain) are highly (less) borrowed firms compared to others located in the remaining five countries. Similarly, the mean $I N T$ is also the highest (lowest) in the case of Omani (Bahraini) firms. Further, the standard deviation of $L E V$ of Omani (Bahraini) firms is 33.22 (8.61), indicating that there are highly (less) dispersed group of business entities in Oman (Bahrain) that are relying heavily on bank financing.

\section{Insert Table 1 Here}

\subsection{Estimated Results of the First Stage Regression Model}

Table 2 includes the estimated coefficients of the first stage regression model under different functional forms, and the corresponding measures of firm efficiency in the region. Both log-likelihood and Akaike Information Criteria (AIC) under each functional form of the revenue frontier model exhibit that all three model specifications are statistically significant and equally comparable to each another. Therefore, the choice among different model specifications does not significantly alter the efficiency measure. Among three functional forms, it is difficult to interpret the coefficients of independent variables under translog and flexible fourier revenue functions because of the presence of combined effects of several second order, interaction and/or trigonometric variables in those specifications. In the case of the fixed-effects functional form, both production and administrative expenses of individual firms are positively correlated with sales revenues, suggesting that firms with high operating expenses are usually high revenue generating firms in the GCC countries. As is evident in Model Specification (1), the coefficients of $\ln C O G S$ and $\ln S G A$ are 0.64 and 0.18 , respectively, significant at the $1 \%$ level. Likewise, the coefficient of $\ln T A$ is 0.20 , significant at the $1 \%$ level, implying that large GCC firms are able to earn high amount of revenues. The result also shows that firm's revenues vary across different industries and countries of the region. 
Panel B of the table reports that the average level of efficiency of GCC firms is $69 \%$ in the fixed-effects model specification, and $62 \%$ in both translog and flexible fourier specifications, significant at the $1 \%$ level. Further, the coefficient of $\theta$ under different revenue functional forms ranges from 2.66 to 3.28 , significant at the $1 \%$ level, suggesting that a significant difference in firm inefficiency exists among individual GCC firms. The result also shows that $\sigma_{u}{ }^{2}$ ranges from $9 \%$ in the fixed-effects functional form to $14 \%$ in both translog and flexible fourier revenue functional forms. In contrast, $\sigma_{v}{ }^{2}$ lies in between $3 \%$ under both translog and flexible fourier functional forms and $9 \%$ under the fixed-effects revenue frontier functional form. Therefore, the manageable fraction of firm inefficiency outweighs the uncontrollable and random portion of inefficiency of GCC firms. This suggests that the current level of operating inefficiency of publicly-listed GCC firms can be reduced further by efficient allocation and utilization of their own internal resources.

Insert Table 2 Here

\subsection{Analysis of Firm Inefficiency in the Region}

Table 3 reports the magnitude of firm inefficiency, derived from all three functional forms, by year, industry, and country. Panel A, for example, includes the distribution of firm inefficiency by year. The estimates reveal that there had been no significant changes in firm inefficiency over the last ten years. Among different sectors, the construction industry is relatively less efficient than other industries in the GCC countries. The average range of firm inefficiency in the construction industry is $47 \%-66 \%$ under both translog and flexible fourier functional forms followed by $30 \%-49 \%$ in the tourism sector, and 32\%-39\% in the service sector. In contrast, the energy, food, and manufacturing industries are relatively less inefficient than other industries in the region. In particular, the level of firm inefficiency in these industries lies in between $27 \%$ and $31 \%$, on average. Finally, the result shows that the publicly-listed firms in Kuwait and Qatar are relatively less efficient than those in other four GCC countries. Notably, the magnitude of firm inefficiency ranges from $30 \%$ to $31 \%$ in Bahrain, from $29 \%$ to $36 \%$ in Oman, from $27 \%$ to $33 \%$ in Saudi Arabia, and from $28 \%$ to $33 \%$ in the UAE.

Insert Table 3 Here

\subsection{Determinants of Firm Inefficiency of GCC Firms}

Table 4 reports the estimated coefficients of the second stage regression model. The dependent variable in each model specification is the measure of firm inefficiency obtained from the first stage regression model. For example, Model Specification (1) includes the inefficiency estimates of individual firms that have been derived from the fixed-effects functional form. Likewise, the inefficiency estimates derived from the translog and flexible-fourier frontier model are considered in Model Specification (2) and (3), respectively. As can be seen in the regression diagnostics including the $R^{2}, F$-values and chi-square values, the Model Specification (1) outperforms the other two models. However, the estimated results across three model specifications remain consistent.

First of all, the estimated results exhibit that there is an insignificant effect of debt financing on firm inefficiency. In particular, the coefficients of $L E V$ and $I N T$ are economically and statistically insignificant across three model specifications. For example, the coefficient of $I N T$ varies from -0.001 in Model Specification (2) to 0.001 in Model Specification (1) with a very low $t$-statistics ranging from -0.31 to 0.65 . This evidence exhibits that an obligation of repaying high amount of principal and interest to lenders does not necessarily create an external pressure on managers to run their firms more efficiently. This finding is not unlikely given that financial institutions are inefficient in the GCC countries, as discussed in Section 3. Therefore, the financial institutions play an insignificant role in improving firm efficiency in the region, which satisfies the initial hypothesis that the external monitoring and disciplinary roles of banks and other financial institutions is not sufficient enough to improve firm efficiency in the GCC countries.

In contrast, the result shows that the coefficient of operating cash flows is negative and statistically significant at the $1 \%$ level, indicating that an increase in firm's internal cash flows reduces firm inefficiency in the GCC countries. For instance, the coefficient of $O C F$ varies from -0.23 in Model Specification (1) to -0.43 in Model Specification (2) and (3). The result also exhibits that an increase in asset turnover reduces firm inefficiency. As an example, the estimated coefficient of $A T$ lies in between -0.07 in Model Specification (1) and -0.11 in both model specifications (2) and (3), significant at the $1 \%$ level. Likewise, there is a significant negative effect of net margin on firm inefficiency, suggesting that an increase in profitability improves operating efficiency of GCC firms. The above findings therefore recommend that the GCC firms can achieve high level of efficiency by improving their own financial performance. Similarly, large companies and firms with high future investment opportunities are less inefficient in the GCC countries. These firms are, in general, well-reputed and well-established business entities in the GCC. Additionally, managers of individual firms with good future investment opportunities operate their 
companies more cautiously so that they can raise their required funds from the financial market at a reasonable cost in future. This in turn increases the current level of firm efficiency.

The estimated results also highlight that there had been no significant changes in firm efficiency over the past ten years in the GCC countries. Further, it exhibits that the publicly-listed firms in Kuwait and Qatar are relatively more inefficient than those in the UAE. Consistent with the previous findings, it is also found that the construction industry is relatively more inefficient than the energy sector in the region. In contrast, the food, manufacturing, and tourism sectors are less inefficient than the energy sector in the GCC countries. Such evidence suggests that the difference in firm inefficiency exists across different industries and countries in the GCC region. Future research can therefore be directed to determine the underlying reasons for such differences in efficiency across industries and individual countries in the GCC.

Insert Table 4 Here

\section{Conclusion}

While several papers examine the efficiency level of financial institutions and stock markets in the Gulf region, this paper aims to investigate firm efficiency for the first time by using a unique data set of a large number of GCC firms over the period 2001-2010. By using stochastic frontier approach, I find that the efficiency level of the publicly-listed GCC firms varies within a range of $62 \%-69 \%$, on average. I further notice that firm efficiency remained the same in the GCC countries over the last ten years. Instead, a significant difference in firm inefficiency exists across individual industries and different countries of the region. In particular, I find that the construction industry is relatively less efficient sector than all other industries in the GCC countries. Further, firms that are located in Kuwait and Qatar are comparatively less efficient than firms operating in other four countries. The result also exhibits that the fraction of manageable firm inefficiency is greater than that of uncontrollable inefficiency (i.e., $9 \%-12 \%$ versus 3\%-9\%) among GCC firms. Therefore, a further improvement in firm efficiency is possible across six GCC countries.

In the second stage of the analysis, I examine whether the disciplinary and monitoring roles of financial institutions can improve firm efficiency. To measure a firm's degree of dependence on banks and other financial institutions, I use firm's leverage and annual interest payments as two separate proxy variables. I posit that firms are required to be more transparent and accountable to outside investors at a high level of external financing, which in turn encourage managers to perform well. I indeed find that high level of bank borrowing does not have any significant impact on improving firm efficiency in the GCC countries. Therefore, the existing roles of financial institutions are not sufficient to improve firm efficiency in the region. In contrast, an improvement in firm's operating cash flows, net margin, and asset turnover decreases the level of firm inefficiency in the GCC countries, suggesting that managing firm's internal resources in an effective manner drives in an increase in efficiency of GCC companies. Likewise, large firms and individual companies with high future investment opportunities are usually more efficient business entities in the region. This evidence has two critical implications in the real world. First, potential investors should choose stocks from the GCC equity markets for their investment after examining firm's financial and operating performances more carefully, and second, policy makers and regulators should take immediate steps in strengthening the roles of banks and financial institutions in the region.

\section{References}

Abdmoulah, W. (2010). Testing the evolving efficiency of Arab stock markets. International Review of Financial Analysis, 19(1),25-34. http://dx.doi.org/10.1016/j.irfa.2009.11.004

Aigner, D. J., Lovell, C. A. K., \& Schmidt, P. (1977). Formulation and Estimation of Stochastic Frontier Production Function Models. Journal of Econometrics, 6(1), 21-37. http://dx.doi.org/10.1016/0304-4076(77)90052-5

Ariss, R. T., Rezvanian, \& R. Mehdian, S. M. (2007). Cost Efficiency, Technological Progress and Productivity Growth of Banks in GCC Countries. International Journal of Business, 12(4), 471-491.

Asiri, B. (2008). Testing weak-form efficiency in a Bahrain stock market. International Journal of Emerging Markets, 3(1), 38-53. http://dx.doi.org/10.1108/17468800810849213

Gallant, A. R. (1981). On the bias in flexible function forms and an essentially unbiased form: The fourier flexible form. Journal of Econometrics, 15(2), 211-245. http://dx.doi.org/10.1016/0304-4076(81)90115-9

Grossman, S., \& Hart, O. (1986). The costs and benefits of ownership: A theory of vertical and lateral integration. Journal of Political Economy, 94(4), 691-719. http://dx.doi.org/10.1086/261404

Harris, M., \& Raviv, A. (1990). Capital structure and the informational role of debt. Journal of Finance, 45(2), 321-349.http://dx.doi.org/10.2307/2328660 
Hassan, K. M., Al-Sultan, W. S., \& Al-Saleem, J. A. (2003). Stock market efficiency in the Gulf Cooperation Council (GCC) countries: The case of Kuwait Stock Exchange. Scientific Journal of Administrative Development, $1(1), 1-21$.

Jensen, M. (1986). Agency costs of free cash flows, corporate finance and takeovers. American Economic Review, 76(2),323-329.

Jensen, M., \& Meckling, W. H. (1976). Theory of the firm: Managerial behavior, agency costs and ownership structure. Journal of Financial Economics, 3(4), 305-360. http://dx.doi.org/10.1016/0304-405X(76)90026-X

Jondrow, J. Lovell, K. Materov, \& I. Schmidt, P. (1982). On the estimation of technical inefficiency in the stochastic frontier production function model. Journal of Econometrics, 19(2-3), 233-238. http://dx.doi.org/10.1016/0304-4076(82)90004-5

Khamis, M., \& Senhadji, A. (2010). Impact of the global financial crisis on the Gulf Cooperation Council countries and challenges ahead, Working Paper, International Monetary Fund, Washington D.C.

Kozmetsky, G., \& Yue, P. (1998). Comparative performance of global semiconductor companies. Omega: International Journal of Management Science, 26(2), 153-175.

Leibenstein, H. (1966). Allocative efficiency vs. X-efficiency. American Economic Review, 56(3), 392-415.

Marie, A., Rao, A., \& Kashani, H. (2009). Cost efficiency and value driver analysis of insurers in an emerging economy. Managerial and Decision Economics, 30(4), 265-280. http://dx.doi.org/10.1002/mde.1454

Mitchell, K., \& Onvural, N. M. (1996). Economies of scale and scope at large commercial banks: Evidence from the fourier flexible functional form. Journal of Money, Credit and Banking, 28(2), 178-199. http://dx.doi.org/10.2307/2078022

Mostafa, M. (2007). Modeling the efficiency of GCC banks: a data envelopment analysis approach. International Journal of Productivity and Performance Management, 56(7), 623-643. http://dx.doi.org/10.1108/17410400710823651

Meeusen, W., \& Broeck, V. (1977). Efficiency estimation from Cobb-Douglas production functions with composed error. International Economic Review, 18(2), 435-444. http://dx.doi.org/10.2307/2525757

Myers, S. (1977). Determinants of corporate borrowing. Journal of Financial Economics, 5(2), 147-175. http://dx.doi.org/10.1016/0304-405X(77)90015-0

Rao, A. (2005). Cost frontier efficiency and risk-return analysis in an emerging market. International Review of Financial Analysis, 14(3), 283-303. http://dx.doi.org/10.1016/j.irfa.2004.10.006

Smith, G. (2007). Random walks in Middle Eastern stock markets. Applied Financial Economics, 17(7), 587-596.

http://dx.doi.org/10.1080/09603100600911200

Squalli, J. (2006). A non-parametric assessment of weak-form efficiency in the UAE financial markets. Applied Financial Economics, 16(18), 1365-1373. http://dx.doi.org/10.1080/09603100500447594

Srairi, S. A. (2010). Cost and profit efficiency of conventional and Islamic banks in GCC countries. Journal of Productivity Analysis, 34(1), 45-62. http://dx.doi.org/10.1007/s11123-009-0161-7

Stulz, R. M. (2000). Financial structure, corporate finance and economic growth. International Review of Finance, 1 (1),11-38.http://dx.doi.org/10.1111/1468-2443.00003

Stulz, R. M. (1990). Managerial discretion and optimal financing policies. Journal of Financial Economics, 26(1), 3-27.http://dx.doi.org/10.1016/0304-405X(90)90011-N

Tseng, F. M. Chiu, Y. J., \& Chen, J. S. (2009). Measuring business performance in the high-tech manufacturing industry: A case study of Taiwan's large-sized TFT-LCD panel companies. Omega: The International Journal of Management Science, 37(3), 686-697.

Walsh, E. J. \& Ryan, J. (1997). Agency and tax explanations of security issuance decisions. Journal of Business Finance \& Accounting, 24(7-8), 943-961. http://dx.doi.org/10.1111/1468-5957.00144

Williams, J. (1987). Perquisites, risk and capital structure. Journal of Finance, 42(1), 29-49. http://dx.doi.org/10.2307/2328417

\section{Notes}

Note 1. In the rest of the paper, GCC firms include firms that are listed in individual stock markets of the GCC countries. The findings are therefore solely based on publicly-listed firms of the region. 
Note 2. The choice of distributional specification is sometimes a matter of computational convenience since the estimation of some frontier models is automated in some statistical software. In this study, the results using half-normal, truncated normal and gamma models are also qualitatively similar. To conserve the space, I do not report the results of the latter three specifications.

Note 3. Kozmetsky and Yue (1998), and Tseng et al. (2009) also use SALES as output, and COGS and SGA as input variables to estimate firm inefficiency.

Note 4. For example, in the case of a country-dummy variable, $U A E$, I assign 1 to those particular firms that are located in the UAE, and 0 for the remaining non-UAE firms.

Table 1. Characteristics of key variables of GCC Firms

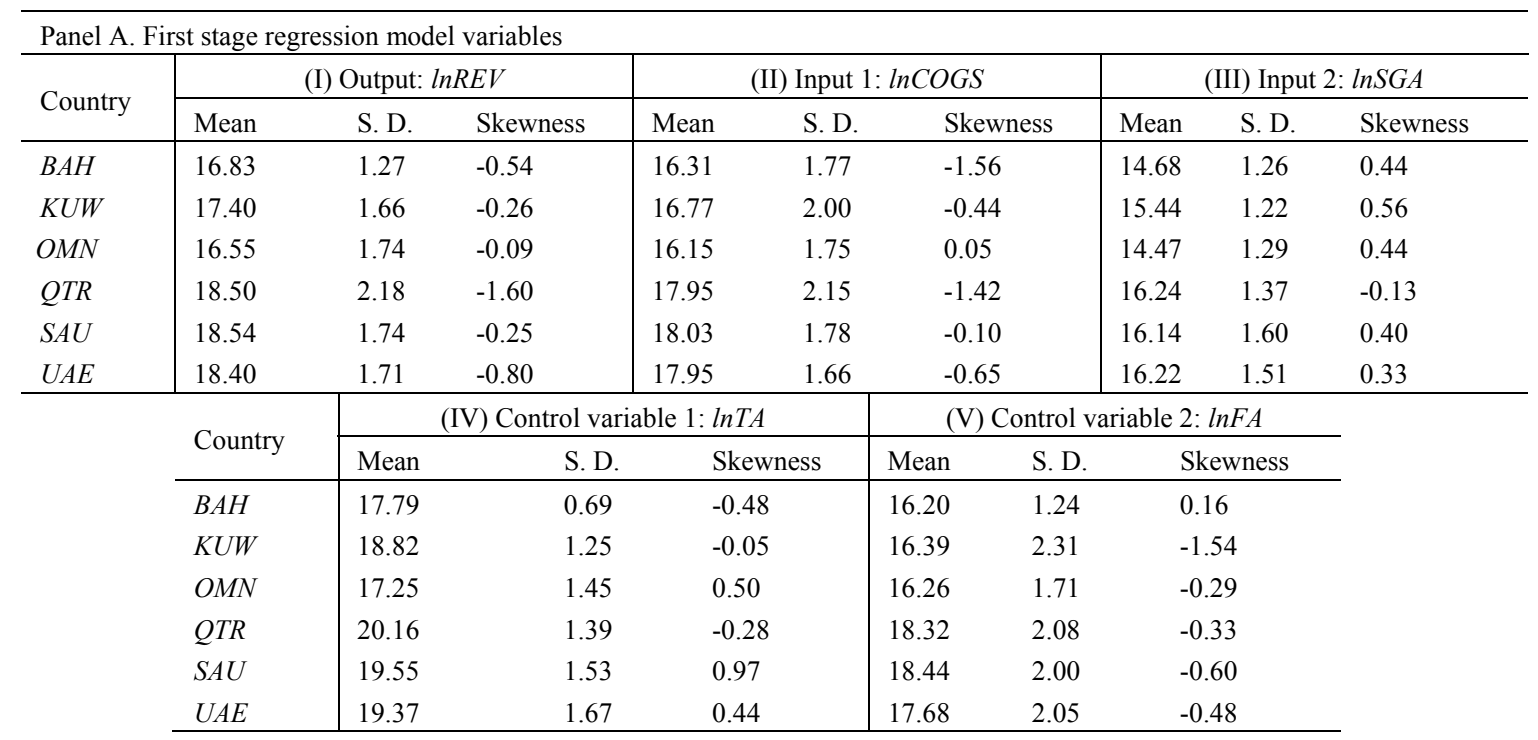

Panel B. Second stage regression model variables

\begin{tabular}{l|lll|lll}
\hline \multirow{2}{*}{ Country } & \multicolumn{3}{|c|}{ (I) $L E V$} & \multicolumn{3}{c}{ (II) INT } \\
\cline { 2 - 6 } & Mean & S. D. & Skewness & Mean & S. D. & Skewness \\
\hline$B A H$ & 11.50 & 8.61 & 0.45 & 0.001 & 0.003 & 2.68 \\
$K U W$ & 21.58 & 15.71 & 0.54 & 0.01 & 0.01 & 1.25 \\
$O M N$ & 40.53 & 33.22 & 1.91 & 0.02 & 0.05 & 14.37 \\
$Q T R$ & 18.85 & 15.50 & 1.83 & 0.01 & 0.01 & 1.53 \\
$S A U$ & 15.31 & 14.44 & 1.10 & 0.01 & 0.01 & 2.55 \\
$U A E$ & 19.91 & 18.56 & 1.08 & 0.01 & 0.01 & 1.95 \\
\hline
\end{tabular}

In the table, S.D. stands for standard deviation. Since we consider logarithm of each variable in the first stage regression model, we calculate summary statistics of log values of respective variables in Panel A. LEV and INT are two separate proxy measures, indicating firm's dependence on banks and other financial institutions. Countries include: BAH (Bahrain), KUW (Kuwait), OMN (Oman), QTR (Qatar), SAU (Saudi Arabia), and UAE (the United Arab Emirates). 
Table 2. Estimating firm inefficiency

\begin{tabular}{|c|c|c|c|c|c|c|}
\hline \multicolumn{7}{|c|}{ Panel A: First-stage regression } \\
\hline \multirow[t]{2}{*}{ Independent variables } & \multicolumn{2}{|c|}{$\begin{array}{l}\text { Model Specification 1: } \\
\text { Fixed-effects }\end{array}$} & \multicolumn{2}{|c|}{$\begin{array}{c}\text { Model Specification 2: } \\
\text { Translog }\end{array}$} & \multicolumn{2}{|c|}{$\begin{array}{l}\text { Model Specification 3: } \\
\text { Flexible Fourier }\end{array}$} \\
\hline & Coefficient & $t$-stat & Coefficient & $t$-stat & Coefficient & $t$-stat \\
\hline Intercept & $0.64 * * *$ & 4.09 & 0.48 & 0.77 & 0.46 & 0.73 \\
\hline $\ln C O G S$ & $0.64 * * *$ & 65.82 & $0.34 * * *$ & 5.06 & $0.35 * * *$ & 5.13 \\
\hline $\ln S G A$ & $0.18 * * *$ & 18.09 & $0.75^{* * *}$ & 8.09 & $0.74 * * *$ & 8.04 \\
\hline $\ln T A$ & $0.20 * * *$ & 14.40 & 0.01 & 0.12 & 0.02 & 0.15 \\
\hline $\ln F A$ & -0.001 & -0.22 & -0.03 & -0.46 & -0.03 & -0.49 \\
\hline $0.5(\ln C O G S)^{2}$ & - & - & $0.03 * * *$ & 21.01 & $0.03 * * *$ & 20.89 \\
\hline $0.5(\ln S G A)^{2}$ & - & - & $0.01 * * *$ & 5.11 & $0.01 * * *$ & 5.05 \\
\hline $0.5(\ln T A)^{2}$ & - & - & $0.04 * * *$ & 10.19 & $0.04 * * *$ & 10.16 \\
\hline $0.5(\ln F A)^{2}$ & - & - & $0.01 * * *$ & 7.19 & $0.01 * * *$ & 7.18 \\
\hline $\ln C O G S \times \ln T A$ & - & - & $-0.09 * * *$ & -14.06 & $-0.09 * * *$ & -13.99 \\
\hline $\ln C O G S \times \ln F A$ & - & - & -0.003 & -1.08 & -0.003 & -1.13 \\
\hline $\ln S G A \times \ln T A$ & - & - & $-0.06^{* * *}$ & -6.17 & $-0.06 * * *$ & -6.15 \\
\hline $\ln S G A \times \ln F A$ & - & - & $-0.01 *$ & -1.74 & -0.01 & -1.62 \\
\hline $\ln T A \times \ln F A$ & - & - & $-0.01 *$ & -1.61 & $-0.01 *$ & -1.67 \\
\hline $\operatorname{Cos} T A$ & - & - & - & - & 0.01 & 0.79 \\
\hline $\operatorname{Cos} F A$ & - & - & - & - & 0.01 & 1.06 \\
\hline $\operatorname{Sin} T A$ & - & - & - & - & 0.01 & 0.88 \\
\hline $\operatorname{Sin} F A$ & - & - & - & - & -0.004 & -0.39 \\
\hline $\operatorname{Cos}(T A+F A)$ & - & - & - & - & 0.001 & 0.11 \\
\hline $\operatorname{Sin}(T A+F A)$ & - & - & - & - & 0.002 & 0.23 \\
\hline$Y R 2$ & 0.05 & 0.53 & 0.07 & 0.92 & 0.07 & 0.96 \\
\hline$Y R 3$ & 0.11 & 1.47 & $0.13^{* *}$ & 2.07 & $0.13^{* *}$ & 2.11 \\
\hline YR4 & 0.12 & 1.61 & $0.13^{* *}$ & 2.19 & $0.13^{* *}$ & 2.23 \\
\hline YR5 & $0.16^{* *}$ & 2.07 & $0.15^{* * *}$ & 2.54 & $0.15^{* * *}$ & 2.57 \\
\hline YR6 & $0.18 * *$ & 2.35 & $0.16^{* * *}$ & 2.73 & $0.17 * * *$ & 2.75 \\
\hline$Y R 7$ & $0.16 * *$ & 2.06 & $0.15^{* * *}$ & 2.56 & $0.16^{* * *}$ & 2.61 \\
\hline YR8 & $0.16^{* *}$ & 2.08 & $0.14^{* *}$ & 2.41 & $0.15^{* * *}$ & 2.46 \\
\hline$Y R 9$ & 0.10 & 1.35 & $0.10^{*}$ & 1.71 & $0.10^{*}$ & 1.74 \\
\hline YR10 & 0.26 & 1.45 & 0.10 & 0.80 & 0.10 & 0.80 \\
\hline CONS & $0.15 * *$ & 2.03 & 0.07 & 1.51 & 0.07 & 1.51 \\
\hline FOOD & -0.30 & -1.06 & $-0.16^{* * *}$ & -5.54 & $-0.16^{* * *}$ & -5.54 \\
\hline$M N G$ & $-0.10^{* *}$ & 2.39 & 0.03 & 1.12 & 0.03 & 1.09 \\
\hline SERV & -0.14 & 0.12 & -0.03 & -1.22 & -0.03 & -1.25 \\
\hline TOUR & -0.17 & 0.99 & $-0.07 *$ & -1.92 & $-0.07 *$ & -1.91 \\
\hline$B A H$ & $0.12 * * *$ & -2.99 & 0.05 & 1.16 & 0.05 & 1.17 \\
\hline$K U W$ & $0.004 * * *$ & -4.09 & 0.00 & 0.10 & 0.001 & 0.05 \\
\hline$O M N$ & $0.03 * * *$ & -3.59 & 0.00 & 0.07 & 0.002 & 0.07 \\
\hline$Q T R$ & $-0.05 * * *$ & -7.87 & -0.05 & -1.29 & -0.05 & -1.32 \\
\hline$S A U$ & $0.06^{* * *}$ & 2.92 & 0.01 & 0.59 & 0.01 & 0.58 \\
\hline
\end{tabular}

Panel B: Summary statistics

\begin{tabular}{|c|c|c|c|c|c|c|}
\hline \multirow[t]{2}{*}{ Indicators } & \multicolumn{2}{|c|}{$\begin{array}{c}\text { Model Specification 1: } \\
\text { Fixed-effects }\end{array}$} & \multicolumn{2}{|c|}{$\begin{array}{c}\text { Model Specification 2: } \\
\text { Translog }\end{array}$} & \multicolumn{2}{|c|}{$\begin{array}{c}\text { Model Specification 3: } \\
\text { Flexible Fourier }\end{array}$} \\
\hline & Estimate & $t$-stat & Estimate & $t$-stat & Estimate & $t$-stat \\
\hline Mean firm efficiency & $0.69 * * *$ & 24.93 & $0.62 * * *$ & 24.36 & $0.62 * * *$ & 24.35 \\
\hline$\sigma_{u}^{2}$ & 0.09 & - & 0.14 & - & 0.14 & - \\
\hline$\sigma_{v}^{2}$ & 0.09 & - & 0.03 & - & 0.03 & - \\
\hline$\Theta$ & $3.28 * * *$ & 23.32 & $2.66 * * *$ & 31.26 & $2.66 * * *$ & 31.20 \\
\hline Log-likelihood & -1198.08 & - & -946.42 & - & -945.06 & - \\
\hline AIC & 1.10 & - & 0.89 & - & 0.89 & - \\
\hline
\end{tabular}

Panel A includes the estimated coefficients of Stochastic Frontier Model (SFM). Panel B reports the estimated firm efficiency in the GCC, and other relevant statistics. In panel A, 2001 is the base year, energy is the base industry, and the United Arab Emirates is the base country. Individual sample years from 2002 to 2010 are defined as $Y R 2$, YR3 and so forth. Industry dummy variables include: CONS (Construction), FOOD (Food), MNG (Manufacturing), SERV (Services) and TOUR (Tourism). Country dummy variables are: $B A H$ (Bahrain), KUW (Kuwait), OMN (Oman), QTR (Qatar) and SAU (Saudi Arabia).***,** and * imply the significance of each coefficient/statistic at the $1 \%, 5 \%$ and $10 \%$ level, respectively. 
Table 3. Distribution of firm inefficiency

Panel A: Distribution by year

\begin{tabular}{l|ll|ll|ll}
\hline \multirow{2}{*}{ Year } & \multicolumn{2}{|c|}{ Specification 1: Fixed-effects } & \multicolumn{2}{c|}{ Specification 2: Translog } & \multicolumn{2}{c}{ Specification 3: Flexible Fourier } \\
\cline { 2 - 7 } & $\begin{array}{l}\text { Mean } \\
\left(u_{t}\right)\end{array}$ & $\begin{array}{l}\text { Mean Difference } \\
\left(u_{t}-u_{t-1}\right)\end{array}$ & $\begin{array}{l}\text { Mean } \\
\left(u_{t}\right)\end{array}$ & $\begin{array}{l}\text { Mean } \\
\text { Difference } \\
\left(u_{t}-u_{t-1}\right)\end{array}$ & $\begin{array}{l}\text { Mean } \\
\left(u_{t}\right)\end{array}$ & $\begin{array}{l}\text { Mean } \\
\text { Difference } \\
\left(u_{t}-u_{t-1}\right)\end{array}$ \\
\hline 2001 & 0.40 & - & - & 0.54 & - \\
2002 & 0.33 & -0.07 & 0.41 & -0.13 & 0.41 & -0.13 \\
2003 & 0.28 & -0.05 & 0.34 & -0.07 & 0.34 & -0.07 \\
2004 & 0.31 & 0.03 & 0.39 & 0.05 & 0.39 & 0.05 \\
2005 & 0.28 & -0.03 & 0.34 & -0.05 & 0.34 & -0.05 \\
2006 & 0.31 & 0.03 & 0.38 & 0.04 & 0.38 & 0.04 \\
2007 & 0.30 & -0.01 & 0.37 & -0.01 & 0.37 & -0.01 \\
2008 & 0.33 & 0.03 & 0.39 & 0.03 & 0.40 & 0.03 \\
2009 & 0.31 & -0.02 & 0.21 & -0.01 & 0.39 & -0.01 \\
2010 & 0.28 & -0.03 & $-0.18^{* * *}$ & 0.22 & $-0.17^{* * *}$ \\
\hline
\end{tabular}

Panel B: Distribution by industry

\begin{tabular}{|c|c|c|c|}
\hline Industries & $\begin{array}{l}\text { Specification 1: } \\
\text { Fixed-effects }\end{array}$ & $\begin{array}{c}\text { Specification 2: } \\
\text { Translog }\end{array}$ & $\begin{array}{l}\text { Specification 3: } \\
\text { Flexible Fourier }\end{array}$ \\
\hline Construction (CONS) & 0.47 & 0.66 & 0.66 \\
\hline Energy $(E N G)$ & 0.27 & 0.31 & 0.31 \\
\hline Food $(F O O D)$ & 0.27 & 0.31 & 0.31 \\
\hline Manufacturing $(M N G)$ & 0.27 & 0.31 & 0.31 \\
\hline Services $(S E R V)$ & 0.32 & 0.39 & 0.39 \\
\hline Tourism $($ TOUR $)$ & 0.30 & 0.49 & 0.49 \\
\hline \multicolumn{4}{|c|}{ Mean differences in firm inefficiency between industries } \\
\hline$E N G-C O N S$ & $-0.20 * * *$ & $-0.35 * * *$ & $-0.35 * * *$ \\
\hline$E N G-F O O D$ & 0.00 & 0.00 & 0.00 \\
\hline$E N G-M N G$ & 0.00 & 0.00 & 0.00 \\
\hline$E N G-S E R V$ & $-0.05^{* *}$ & $-0.08^{* *}$ & $-0.08 * *$ \\
\hline$E N G-T O U R$ & -0.03 & $-0.18^{* *}$ & $-0.18^{* *}$ \\
\hline FOOD - CONS & $-0.20 * * *$ & $-0.35 * * *$ & $-0.35 * * *$ \\
\hline$F O O D-M N G$ & 0.00 & 0.00 & 0.00 \\
\hline FOOD - SERV & $-0.05 * *$ & $-0.08^{* *}$ & $-0.08^{* *}$ \\
\hline FOOD - TOUR & -0.03 & $-0.18 * *$ & $-0.18^{* *}$ \\
\hline$M N G-C O N S$ & $-0.20 * * *$ & $-0.35 * * *$ & $-0.35 * * *$ \\
\hline$M N G-S E R V$ & $-0.05 * *$ & $-0.08 * * *$ & $-0.08 * * *$ \\
\hline$M N G-T O U R$ & -0.03 & $-0.18^{* *}$ & $-0.18 * *$ \\
\hline$C O N S-S E R V$ & $0.15^{* * *}$ & $0.27 * * *$ & $0.27 * * *$ \\
\hline CONS - TOUR & $0.17 * * *$ & $0.17 *$ & $0.17^{*}$ \\
\hline SERV - TOUR & 0.02 & -0.10 & -0.10 \\
\hline
\end{tabular}

Panel C: Distribution by country

\begin{tabular}{l|l|l|l}
\hline \multirow{2}{*}{ Gulf countries } & \multicolumn{1}{c|}{$\begin{array}{c}\text { Specification 1: } \\
\text { Fixed-effects }\end{array}$} & \multicolumn{1}{c}{$\begin{array}{c}\text { Specification 2: } \\
\text { Translog }\end{array}$} & $\begin{array}{c}\text { Specification 3: } \\
\text { Flexible Fourier }\end{array}$ \\
\cline { 2 - 4 } & \multicolumn{1}{|c}{$u_{t}$} & 0.31 \\
Bahrain $(B A H)$ & 0.30 & 0.31 & 0.45 \\
Kuwait $(K U W)$ & 0.34 & 0.45 & 0.36 \\
Oman $(O M N)$ & 0.29 & 0.36 & 0.45 \\
Qatar $(Q T R)$ & 0.34 & 0.45 & 0.33 \\
Saudi Arabia $(S A U)$ & 0.27 & 0.33 & 0.33 \\
The United Arab Emirates (UAE) & 0.28 & 0.33 & $-0.14^{* * *}$ \\
\hline Mean differences in firm inefficiency between two GCC countries & -0.05 \\
\hline BAH-KUW & $-0.05^{*}$ & $-0.14^{* * *}$ & -0.14 \\
BAH-OMN & 0.01 & -0.05 & -0.02 \\
$B A H-Q T R$ & -0.04 & -0.14 & -0.02 \\
$B A H-S A U$ & 0.03 & -0.02 & -0.02 \\
$B A H-U A E$ & 0.02 & \multicolumn{2}{c}{}
\end{tabular}




\begin{tabular}{|c|c|c|c|}
\hline$K U W-O M N$ & $0.05 * *$ & $0.09^{* * *}$ & $0.09 * * *$ \\
\hline$K U W-Q T R$ & 0.00 & 0.00 & 0.00 \\
\hline$K U W-S A U$ & $0.07 * * *$ & $0.12 * * *$ & $0.12 * * *$ \\
\hline$K U W-U A E$ & $0.06^{* *}$ & $0.12 * *$ & $0.12 * *$ \\
\hline$O M N-Q T R$ & -0.05 & -0.09 & -0.09 \\
\hline$O M N-S A U$ & 0.02 & 0.03 & 0.03 \\
\hline$O M N-U A E$ & 0.01 & 0.03 & 0.03 \\
\hline$Q T R-S A U$ & 0.07 & 0.12 & 0.12 \\
\hline QTR - UAE & 0.06 & 0.12 & 0.12 \\
\hline$S A U-U A E$ & -0.01 & 0.00 & 0.00 \\
\hline
\end{tabular}

Table 4. Determinants of firm inefficiency

\begin{tabular}{|c|c|c|c|c|c|c|}
\hline \multirow{2}{*}{$\begin{array}{l}\text { Independent } \\
\text { variables }\end{array}$} & \multicolumn{2}{|c|}{$\begin{array}{l}\text { Model Specification 1: } \\
\text { Fixed-effects }\end{array}$} & \multicolumn{2}{|c|}{ Model Specification 2: Translog } & \multicolumn{2}{|c|}{$\begin{array}{l}\text { Model Specification 3: } \\
\text { Flexible Fourier }\end{array}$} \\
\hline & $0.49 * * *$ & $0.40 * * *$ & $0.41^{*}$ & $0.41 *$ & $0.58 * * *$ & $0.41 *$ \\
\hline$L E V$ & -0.001 & - & 0.00 & - & 0.00 & - \\
\hline$I N T$ & - & 0.001 & - & -0.001 & - & -0.00 \\
\hline$O C F$ & $-0.23 * * *$ & $-0.25 * * *$ & $-0.39 * * *$ & $-0.43 * * *$ & $-0.39 * * *$ & $-0.43 * * *$ \\
\hline$A T$ & $-0.09 * * *$ & $-0.07 * * *$ & $-0.11 * * *$ & $-0.08 * * *$ & $-0.11 * * *$ & $-0.08 * * *$ \\
\hline$N M$ & $-0.01 * * *$ & $-0.01 * *$ & $-0.01 *$ & -0.002 & $-0.01 *$ & -0.002 \\
\hline$G R$ & 0.01 & 0.002 & 0.01 & 0.004 & 0.01 & 0.004 \\
\hline INVOPP & $-0.03 * * *$ & $-0.04 * * *$ & $-0.06 * * *$ & $-0.06 * * *$ & $-0.06 * * *$ & $-0.06 * * *$ \\
\hline SIZE & $-0.01 * *$ & $-0.01 *$ & $-0.02 * * *$ & -0.010 & $-0.02 * * *$ & -0.01 \\
\hline$Y R 2$ & 0.06 & 0.07 & 0.09 & 0.10 & 0.10 & 0.11 \\
\hline$Y R 3$ & 0.06 & 0.07 & 0.09 & 0.09 & 0.10 & 0.10 \\
\hline$Y R 4$ & 0.03 & 0.04 & 0.07 & 0.07 & 0.07 & 0.07 \\
\hline$Y R 5$ & 0.04 & 0.05 & 0.06 & 0.07 & 0.07 & 0.07 \\
\hline YR6 & 0.04 & 0.06 & 0.07 & 0.08 & 0.07 & 0.09 \\
\hline$Y R 7$ & 0.04 & 0.04 & 0.04 & 0.04 & 0.04 & 0.04 \\
\hline$Y R 8$ & 0.03 & 0.04 & 0.03 & 0.04 & 0.03 & 0.04 \\
\hline$Y R 9$ & 0.03 & 0.04 & 0.04 & 0.06 & 0.05 & 0.06 \\
\hline YR10 & 0.14 & 0.11 & -0.08 & -0.01 & -0.07 & -0.01 \\
\hline CONS & $0.08 * * *$ & $0.05^{* *}$ & $0.11^{* * *}$ & $0.10^{* * *}$ & $0.11^{* * *}$ & $0.10^{* * *}$ \\
\hline FOOD & $-0.07 * * *$ & $-0.05 * * *$ & $-0.09 * * *$ & $-0.06^{*}$ & $-0.10 * * *$ & $-0.06^{*}$ \\
\hline$M N G$ & $-0.04 * *$ & $-0.04 * *$ & $-0.07 * *$ & -0.04 & $-0.06^{* *}$ & -0.04 \\
\hline$S E R V$ & -0.01 & 0.003 & -0.01 & 0.03 & -0.004 & 0.03 \\
\hline TOUR & $-0.11 * * *$ & $-0.09 * * *$ & $-0.11 * *$ & -0.05 & $-0.11^{* *}$ & -0.06 \\
\hline$B A H$ & $0.11 * *$ & $0.04 *$ & 0.11 & 0.02 & 0.11 & 0.02 \\
\hline$K U W$ & 0.02 & 0.02 & $0.08^{* *}$ & $0.09 * * *$ & $0.08 * * *$ & $0.09 * * *$ \\
\hline$O M N$ & -0.003 & 0.01 & 0.02 & 0.04 & 0.02 & 0.04 \\
\hline$Q T R$ & 0.02 & 0.02 & $0.10 * *$ & $0.09 * *$ & $0.10 * *$ & $0.09 * *$ \\
\hline$S A U$ & 0.03 & 0.02 & $0.10^{* * *}$ & $0.08 * * *$ & $0.10^{* * *}$ & $0.07 * * *$ \\
\hline$N$ & 1410 & 1810 & 1410 & 1810 & 1410 & 1810 \\
\hline$R^{2}$ & 0.22 & 0.20 & 0.21 & 0.18 & 0.21 & 0.18 \\
\hline$F$-stat & $15.41 * * *$ & $17.50 * * *$ & $14.06^{* * *}$ & $15.34 * * *$ & $14.07 * * *$ & $15.33 * * *$ \\
\hline Chi-sq & $358.63 * * *$ & $411.40 * * *$ & $330.75 * * *$ & $365.39 * * *$ & $330.81 * * *$ & $365.09 * * *$ \\
\hline
\end{tabular}

The coefficients are obtained from the panel regression estimation method. The dependent variable is firm inefficiency estimated from the first stage regression model. The extent to which firms are involved with financial institutions is measured by firms' leverage (LEV) and interest payments $(I N T)$. Other independent variables include: firm's operating cash flows $(O C F)$, asset turnover $(A T)$, net margin $(N M)$, sales growth $(G R)$, future investment opportunity (INVOPP), and firm size (SIZE). 2001 is the base year, energy is the base industry, and the United Arab Emirates is the base country. Individual sample years from 2002 to 2010 are defined as $Y R 2, Y R 3$ and so forth. Industry dummy variables include: CONS (Construction), FOOD (Food), MNG (Manufacturing), SERV (Services) and TOUR (Tourism). Country dummy variables are: BAH (Bahrain), KUW (Kuwait), OMN (Oman), QTR (Qatar) and SAU (Saudi Arabia). ***,** and * imply the significance of each coefficient/statistic at the $1 \%, 5 \%$, and $10 \%$ level, respectively. 